\title{
The Impact of Deepwater Horizon Oil Spill on Petroleum Hydrocarbons in Surface Waters of the Northern Gulf of Mexico
}

\author{
Zhanfei Liu ${ }^{1 *}$, Jiqing Liu ${ }^{1}$, Wayne S. Gardner ${ }^{1}$, G. Christopher Shank ${ }^{1}$, Nathaniel, E. \\ Ostrom $^{2}$ \\ ${ }^{1}$ Marine Science Institute, The University of Texas at Austin, Port Aransas, TX 78373 \\ ${ }^{2}$ Department of Zoology, Michigan State University, East Lancing, MI 48824
}

*Corresponding Author:

Zhanfei Liu

Marine Science Institute

The University of Texas at Austin

Port Aransas, TX 78373-5015

Email: zhanfei.liu@mail.utexas.edu

Phone: 361-749-6783

Fax: 361-749-6761 


\section{Abstract}

This study evaluated impacts of the BP Deepwater Horizon (DWH) oil spill on petroleum hydrocarbons in surface waters of the Louisiana continental shelf in northern Gulf of Mexico. Surface water ( top 5cm) without visible oil was collected from three cruises in May 2010 during the oil spill, August 2010 after the well was capped, and May 2011 one year after the spill. Concentrations of total dissolved $n$-alkanes $\left(\mathrm{C}_{9}-\mathrm{C}_{35}\right)$ in surface seawater were more than an order of magnitude higher in May 2010 than August 2010 and May 2011, indicating contamination by the $D W H$ oil spill. This conclusion was further supported by more abundant smaller $n$-alkanes $\left(\mathrm{C}_{9}-\mathrm{C}_{13}\right)$, together with pristane and phytane, in May than August 2010 samples. In contrast, even carbon-numbered dissolved $n$-alkanes $\left(\mathrm{C}_{14}-\mathrm{C}_{20}\right)$ dominated the May 2011 samples, and this distribution pattern of dissolved $n$-alkanes is the first documentation for water samples in the northern Gulf of Mexico. However, this pattern was not observed in May 2011 suspended particles except for Sta. OSS. This decoupling between dissolved and particle compositions suggests that either these even carbon-numbered $n$-alkanes originated from bacteria rather than algae, or that the alkanes in the shelf were transported from elsewhere.

Concentrations of polycyclic aromatic hydrocarbons (PAHs) in suspended particles were 5 times higher on average in May $2010\left(83-252 \mathrm{ng} \mathrm{L}^{-1}\right)$ than May $2011\left(7.2-83 \mathrm{ng} \mathrm{L}^{-1}\right)$, also indicating contamination by the $D W H$ oil spill. Application of a biomarker ratio of $17 \alpha(\mathrm{H}), 21 \beta(\mathrm{H})-30$ norhopane over $17 \alpha(\mathrm{H}), 21 \beta(\mathrm{H})$-hopane confirmed that suspended particles from at least two stations were contaminated by the $D W H$ oil spill in May 2010. Taken together, these results showed that surface waters of the sampling area in May 2010 were contaminated by the oil spill, but also that rapid weathering and/or physical dilution quickly reduced hydrocarbon levels by August 2010. 
Key Words: Deepwater Horizon oil spill; northern Gulf of Mexico; $n$-alkanes; polycyclic aromatic hydrocarbons; surface water; suspended particles 


\section{Introduction}

As one of the most severe marine oil disasters, the Deepwater Horizon (DWH) oil spill released approximately 4.9 million barrels of oil from April 20 to July 15, 2010, and 2 million gallons of chemical dispersants were applied to the Gulf waters (Crone and Tolstoy, 2010; Joye et al., 2011; Kujawinski et al., 2011; Leifer, 2010; Reddy et al., 2011). The oil and chemical dispersant released during the $D W H$ spill have both short- and long-term impacts on northern Gulf of Mexico ecosystems (Rabalais, 2011). Most studies of the $D W H$ oil spill have focused on the "visible" oil, including the underwater oil plume (Camilli et al., 2010; Hazen et al., 2010), methane (Joye et al., 2011; Kessler et al., 2011), dispersant (Kujawinski et al., 2011), and oil mousses on sea surface and shorelines (Kostka et al., 2011; Liu and Liu, 2013; Liu et al., 2012). Surface waters without visible oil have not been emphasized in the affected northern Gulf, despite their susceptibility to contamination and importance as ecological habitats.

Due to its lower density than water, a major fraction $(>65 \%)$ of the oil rose to the sea surface after the DWH oil spill (Ryerson et al., 2012), and was then evaporated or washed to shorelines by currents. Dynamic physical forcing processes may enhance oil emulsification and dilute oil components by mixing them with non-contaminated waters. The dissolution of petroleum hydrocarbons was perhaps enhanced by the application of 1.4 million gallons of dispersant on sea surface oil during the oil spill between May 15 to July 12, 2010 (Kujawinski et al., 2011). Therefore, the "soluble" hydrocarbons may have contaminated surface waters during their physical transport from the accident site to shorelines. For example, enhanced levels of polycyclic aromatic hydrocarbons (PAHs), a major group of crude oil, were detected in the shoreline seawater without visible oil along the northern Gulf of Mexico after the $D W H$ oil spill (Allan et al., 2012). 
The crucial ecological role of coastal surface waters in northern Gulf of Mexico ecosystems merits study of the potential effects of contamination by the DWH oil spill. For example, surface water provides important habitats for fish larvae and zooplankton. The Louisiana continental shelf provides important fishery nursery beds that service $75 \%$ of all fisheries landings in the Gulf of Mexico (Cowan et al., 2008). Surface water may serve as an important media for trophic transfer of oil carbon from oil slick and mousse contamination during the transport from the accident site to shorelines. Indeed, oil carbon has been detected in suspended particles and mesozooplankton in the shelf region off Mobile Bay in northern Gulf of Mexico from June to August, 2010 (Graham et al., 2010). PAHs are particularly toxic to small organisms, especially fish larvae living at sea surface (Incardona et al., 2004). Other ecological impacts of surface water oil contamination include reduced primary production in the water column caused by attenuation of sunlight penetration. Further, gas exchange rates between the ocean surface and atmosphere are inhibited by organic films (Hebrard et al., 2009; Mackay, 1982), which may exacerbate the development of hypoxic conditions in the northern Gulf of Mexico (Rabalais et al., 2010).

Petroleum hydrocarbons may not last long in surface waters, due to weathering processes including evaporation, dissolution, biodegradation, and photooxidation (Fingas, 1999; Hunt, 1996; Liu and Liu, 2013; Liu et al., 2012; Plata et al., 2008). In the northern Gulf, oil degradation may be enhanced at the sea surface by high water temperatures and strong solar irradiance. The $D W H$ oil is susceptible to microbial degradation, as observed in the deep ocean, at the beach, or in oligotrophic surface waters (Edwards et al., 2011; Hazen et al., 2010; Kostka et al., 2011; Liu and Liu, 2013; Valentine et al., 2010). Microbes play an essential role in degrading oil in marine environments, but bacterial growth may be limited by nutrient 
availability, such as phosphate in the oligotrophic Gulf of Mexico (Edwards et al., 2011;

Pomeroy et al., 1995). However, our study area in the northern Gulf of Mexico is influenced largely by the Mississippi River plume (Rabalais et al., 2002), which provides adequate nutrients for bacteria degradation.

In this study, we examined the fate of petroleum hydrocarbons in surface waters of the northern Gulf of Mexico and evaluated the extent of their weathering with time. We measured petroleum hydrocarbons, including $n$-alkanes, pristane, phytane, and PAHs in both dissolved and particulate phases in surface samples collected in May and August 2010 and May 2011. Our overall hypothesis is that the surface water without visible oil in the near-shore northern Gulf of Mexico was contaminated by oil from the spill. Specifically, two questions are addressed: (1) How extensively was the sea surface contaminated by the $D W H$ oil spill, and (2) How did the composition of the oil spill contaminants such as $n$-alkanes change over time on the sea surface?

\section{Methods}

\subsection{Sample collection}

Surface water samples were collected at 6 stations along the Louisiana continental shelf during three cruises within 100-300 km of the DWH spill site: May 20-27 and August 3-10, 2010, and May 19-25, 2011 (Fig. 1 and Table 1). Sampling stations were named (in part) according to the long-term hypoxia study in this area (Lin et al., 2011; Rabalais et al., 2002). These stations include hypoxic continental shelf waters (C6, F5, and B6 or B7), the Mississippi River mouth waters (MRM), the shelf waters east of the Mississippi River birdfoot (CT), and waters off the continental shelf near the DWH oil spill site (OSS) (Table 1). At each station, 4-6 L of surface water ( top $5 \mathrm{~cm}$ ) without visible oil sheen or slick was collected using either a 
polypropylene bucket or a peristaltic pump. The sampling depth was controlled by careful bucket sampling or by the Tygon tubing $(5 \mathrm{~cm}$ in the water) connected to the peristaltic pump. The $5 \mathrm{~cm}$ of surface water sampling can be viewed only as an approximate depth due to the updown movement of the ship caused by waves, although sea conditions were relatively calm during sampling. The water was filtered immediately through pre-combusted $47-\mathrm{mm} 0.7 \mu \mathrm{m}$ GF/F filters (Whatman) in a glass filtration apparatus. Both the filters and filtrates were stored frozen at $-20^{\circ} \mathrm{C}$ until hydrocarbon extraction. Aliquots of the filtrates $(3 \times 20 \mathrm{~mL}$ subsamples $)$ were frozen for analyses of dissolved organic carbon (DOC). Before use, all glassware was combusted at $450^{\circ} \mathrm{C}$ overnight and the plastic items were sequentially cleaned with acid and dichloromethane (DCM). Surface oil mousse, defined as oil emulsified with water, was observed only at CT and OSS stations during the May 2010 cruise, (Liu et al., 2012), and these stations were sampled last to minimize contamination from the ship and gear on deck.

\subsection{Chemical and statistical analyses}

\subsubsection{Organic carbon and nitrogen analyses}

Particulate organic carbon (POC) and particulate nitrogen (PN) were measured with a Carlo Erba model $1602 \mathrm{CNS}$ analyzer after the filters were acidified under acid fumes (HCl) to remove inorganic carbon (Liu et al., 2005). The precision for this analyzer is $\pm 5 \%$ for $\mathrm{N}$ and $\pm 2 \%$ for C. Dissolved organic carbon (DOC) was measured using a Shimadzu TOC-V CSH analyzer. Duplicate analyses agreed within $10 \%$.

\subsection{2. n-Alkane and polycyclic aromatic hydrocarbon (PAHs) analysis}

Filters were extracted using DCM in Soxhlet apparatus for $20 \mathrm{~h}$, and deuterated hexadecane- $d_{34}$, acenaphthene $\left(\right.$ Ace- $\left.d_{10}\right)$, phenanthrene $\left(\right.$ Phe- $\left.d_{10}\right)$ and benzo[a]pyrene(BaP- $\left.d_{12}\right)$ were added as surrogate standards. Filtered surface water (2-4 L) was extracted twice with DCM 
$(150 \mathrm{~mL})$ in a separatory funnel, and the same set of deuterated standards were added (Short and Harris, 1996). The DCM extracts were combined, filtered through $20 \mathrm{~g}$ anhydrous sodium sulfate, concentrated by a Rotovap and exchanged with hexane to a final volume of $0.5 \mathrm{~mL}$. Alkanes and PAHs in the extracts were separated and analyzed on a gas chromatography-mass spectrometry system (Shimadzu GC-MS QP2010 plus), with a RXi-1MS capillary column (28 m x $0.18 \mathrm{~mm}, 0.18 \mu \mathrm{m}$ film thickness) (Liu et al., 2012). Briefly, the injection volume was $1 \mu \mathrm{L}$ with a split ratio of $1 / 20$. The temperature of the column was ramped from 60 to $240^{\circ} \mathrm{C}$ at a rate of $10^{\circ} \mathrm{C} \mathrm{min}-1$, and then increased to $280^{\circ} \mathrm{C}$ at a rate of $4^{\circ} \mathrm{C} \mathrm{min}^{-1}$ and held for $3 \mathrm{~min}$. The GCMS analysis was performed using selective ion monitoring mode to detect $n$-alkanes and PAH, with 200 milliseconds dwell time per ion. Quantification was based on internal standards including fluorene- $d_{10}$ and benzo[ $[e]$ pyrene- $d_{12}$, and external standards of PAH-3 (Sigma). For the alkanes including pristane and phytane, peak integration was based on $\mathrm{m} / \mathrm{z} 57$ with reference ions of 71 and 85 , and quantification was based on the internal standard hexadecane- $d 34$ and external standards of $n$-alkanes $\mathrm{C}_{8}-\mathrm{C}_{40}$ (Sigma). The recovery of hexadecane- $d_{34}$ was $77.1 \pm 11.0 \%$. In addition, we also quantified $17 \alpha(\mathrm{H}), 21 \beta(\mathrm{H})$-hopane, an inert petroleum biomarker. Its structure identification was based on both scan and SIM mode data, and the peak integration was based on a base peak m/z 191 with a reference m/z 177 (Wang et al., 2004b).

\subsubsection{Principal component analysis (PCA)}

PCA is a multivariate regression analysis that reduces the number of variables in a data set into two or three major principal components, which can be used to investigate compositional differences among samples (e.g., Liu et al., 2013; Meglen, 1992; Yunker et al., 1995). With MATLAB, PCA was performed on compositions (weight \%) of dissolved and particulate alkanes 
in surface water. For comparison, $n$-alkane data of an oil mousse collected at Sta. OSS during the oil spill was included to the data matrix (Liu et al., 2012).

\section{Results and Discussion}

\subsection{The chemical properties of surface water}

Surface water salinities ranged from 6.7 to 34.3 at the 6 stations during the May 2010 cruise (Table 1). Low salinities at stations B6 and MRM were caused by freshwater input from the Mississippi River (Dagg et al., 2007). Sea surface temperatures were above $26^{\circ} \mathrm{C}$ at all stations in May 2010. Dissolved oxygen was greater than 100\% saturation, except for stations MRM and OSS with saturation values of approximately 77\%. All stations except station F5 had high chlorophyll fluorescence, suggesting high phytoplankton biomass in the Mississippi River plume in May 2010 (Lohrenz et al., 2008). Nitrate concentrations at stations B6 and MRM were 25.2 and $78.2 \mu \mathrm{M}$, respectively, reflecting high freshwater discharge and nitrate input from the Mississippi River. In contrast, nitrate concentrations at stations F5 and C6 were only about 1 $\mu \mathrm{M}$ and salinities were 34 and 29 , respectively.

During the August 2010 cruise, salinities ranged from 21.6 to 28.6, generally higher than those during the May 2010 cruise, in particular for stations B6 (26.0 vs. 14.3) and MRM (22.6 vs. 6.7). This pattern likely reflected a reduced Mississippi River freshwater input in August compared with May. Surface water temperatures at all stations were above $31^{\circ} \mathrm{C}$ in August 2010, 3-5 ${ }^{\circ} \mathrm{C}$ higher than in May 2010. Fluorescence values at stations C6, CT and OSS were 3-5 times lower in August 2010 than in May 2010, suggesting lower phytoplankton biomass. Physical parameters and nitrogen levels during the May 2011 cruise were similar to those of May 2010 cruise. 
DOC concentrations ranged from 96-320 $\mu \mathrm{M}$ in both May and August 2010 (Table 1).

Concentrations of POC ranged from 11-92 $\mu \mathrm{M}$ during the two cruises, except for station MRM (Mississippi River mouth) with exceptionally high POC, $123 \mu \mathrm{M}$ in May and $257 \mu \mathrm{M}$ in August (Table 1). DOC and POC concentrations were elevated at mid-salinities (Fig. 2a, 2b), perhaps caused by phytoplankton production and heterotrophic processes in the Mississippi River plume (Benner and Opsahl, 2001; Dagg et al., 2004). Concentrations of DOC and POC are consistent with previous studies in this region (Benner and Opsahl, 2001; Bianchi et al., 2009; Guo et al., 2009; Pakulski et al., 2000; Shank and Evans, 2011; Wang et al., 2004a; Wysocki et al., 2006), suggesting that the large bulk organic carbon pool was not impacted to levels that can be differentiated from natural variations. However, POC C/N atomic ratios, presumably a more sensitive indicator for hydrocarbon contamination, at CT and OSS in May (11.0 and 9.6) were significantly ( $t$ test, $\mathrm{p}<0.05$ ) higher than in August (7.5 and 6.9) (Table 1; Fig. 2c). Considering that oil was observed at both stations during the May cruise (Liu et al., 2012), we suspect that the higher $\mathrm{C} / \mathrm{N}$ ratios may have resulted from particle contamination by the oil. This conclusion was supported by the relatively high concentrations of particulate alkanes and PAHs at both stations (see sections 3.3 and 3.4).

\subsection{Dissolved alkanes in surface water}

Concentrations of dissolved alkanes ranged from $94-150 \mu \mathrm{g} \mathrm{L}^{-1}$ in the surface water of four stations (F5, C6, OSS and MRM) in May 2010, but decreased by one order of magnitude in August 2010 (2.8 to $10.6 \mu \mathrm{g} \mathrm{L}^{-1}$ ) (Fig. 3a). Even though the levels in May 2012 increased to 10.8-34.7 $\mu \mathrm{g} \mathrm{L}^{-1}$, they were still 5-10 times lower than in May 2010. The high levels of dissolved $n$-alkanes in May 2010 were similar to petroleum-contaminated surface waters (200 $\mu \mathrm{g}$ $\mathrm{L}^{-1}$ ) in the Rio de La Plata estuary, Argentina (Colombo et al., 1989). This result further 
suggests that the surface water of the surveyed area was contaminated by the $D W H$ oil spill in May 2010, but by August 2010, concentrations were within typical ranges reported in surface coastal waters with trace effects of petroleum such as Chesapeake Bay $\left(3.16 \pm \mu \mathrm{g} \mathrm{L}^{-1}\right)$ (Hardy et al., 1990), although still higher than those in the open ocean or areas less impacted by human activities (0.3-0.6 $\left.\mu \mathrm{g} \mathrm{L}^{-1}\right)$ (Stortini et al., 2009). Biological sources, such as algae and bacteria, could contribute to the high alkane levels, but this conclusion seems unlikely because concentrations of POC, an indicator of biological production, changed little from May to August (Table 1). The significantly lower alkane levels ( $t$-test, $\mathrm{p}=0.0002)$ in May 2011 also supports the idea that surface waters were contaminated in May 2010. This idea is further supported by the presence of an unresolved complex mixture (UCM) in the GC-MS chromatograms of the May 2010 samples, particularly in those samples with high $n$-alkane concentrations (F5, C6, OSS and MRM). In contrast, UCM was not observed in the May 2011 samples (Fig. S1 as a typical example). In addition, a satellite image of the Mississippi River Delta shows oil slicks on the sea surface on May 24, 2010, near our sampling locations (Fig. S2). Note that although the concentrations of $n$-alkanes were greatly enhanced during the May 2010 cruise, they comprised less than $10 \%$ of the total DOC concentration. By contrast, $n$-alkanes represented less than $0.5 \%$ of the DOC concentration in August. The small percentages of $n$-alkanes explain why the total DOC pool was not altered to a level that can be differentiated from the natural variations.

The composition of $n$-alkanes in samples provides source and diagenesis information. Dissolved $n$-alkanes in surface waters ranged in size from $\mathrm{C}_{9}$ - $\mathrm{C}_{35}$ in both May and August 2010 cruises, and were dominated by $\mathrm{C}_{14}-\mathrm{C}_{30}$ (typical $n$-alkane composition from station $\mathrm{C} 6$ is shown in Fig. 4a). The $n$-alkanes with more than 23 carbon atoms exhibited a predominance of oddnumbered compounds (Fig. 4a), suggesting a terrestrial plant contribution from Mississippi River 
runoff (Hunt, 1996; Liu et al., 2013; Meyers, 1997; Yunker et al., 1995). The carbon preference index (CPI), based on ratios of odd over even carbon-numbered $n$-alkanes (n>23), can differentiate biogenic vs. petrogenic sources for the $n$-alkanes in environment samples (Wang et al., 1999). CPI values in May and August 2010 samples ranged from 1.4-2.9 (Table 1). May samples had lower averaged CPI (1.8) than August samples (2.0), but were no different statistically at the $95 \%$ significant level using Student $t$ - and F-tests. These CPI values were higher than those for the oil mousse and oil sheen (1.1-1.2) collected in May 2010 which were typical ( 1) of direct oil sources (Liu et al., 2012; Wang and Fingas, 2003), but they still suggest a certain degree of petroleum contamination at these stations.

In contrast to results of May and August 2010, dissolved $n$-alkanes in May 2011 were dominated by even carbon-numbered $n$-alkanes, mainly from $\mathrm{C}_{14-} \mathrm{C}_{20}$ (Fig. 4b, Fig. S1c). This pattern was also reflected by the low CPIs (0.11-0.25) in these samples (Table 1$)$. Additional data on Sta. C6 sample collected in May 2013 showed a similar pattern (data not shown). This predominance of even carbon-numbered $n$-alkanes is somewhat surprising, as odd carbonnumbered $n$-alkanes are often dominant in natural environments, such as long $n$-alkanes $(\mathrm{n}>23)$ of terrestrial plant wax (Liu et al., 2013; Meyers, 1997). However, the predominant pattern of even carbon-numbered $n$-alkanes has been frequently observed in both surface sediments and the water column of marine environments (Elias et al., 1997; Hu et al., 2009; Lu and Meyers, 2009; Nishimura and Baker, 1986). Even carbon-numbered $n$-alkanes can be produced from diagenetic reduction of fatty acids or alcohols (Simoneit, 1977), but this explanation would not be predicted for oxygenated surface waters (Table 1). Instead, biogenic sources from diatom or bacteria may contribute to this even dominance of $n$-alkanes (Grimalt and Albaigés, 1987; Nishimura and Baker, 1986). For example, the predominance of even carbon-numbered $n$-alkanes $(n<24)$ in the 
Amazon continental shelf was linked to microbial alteration of algal detritus (Elias et al., 1997). One possible source for the even carbon-numbered $n$-alkanes is from chain-forming Skeletonema costatum (Schenck et al., 1969), an abundant genus in the Mississippi River plume water (Dagg and Breed, 2003). It is also possible these $n$-alkanes were derived from microorganisms that were sustained by the oil contaminants after the oil spill, as this phenomenon has been reported in Lake Erie sediments (Lu and Meyers, 2009). The production of certain maximum $n$-alkanes from microorganisms may depend on environment conditions (Elias et al., 1997; Jones and Young, 1970), which may be optimal for even-numbered n-alkanes in the plumes of Mississippi and Amazon Rivers. Indeed, $n$-alkanes have been shown to be dominated by even-numbered ones in surface sediments of the northern Gulf of Mexico at a station $<20 \mathrm{~km}$ away from Sta. OSS (Nishimura and Baker, 1986). Our results support the conclusion that these $n$-alkanes were from marine organisms and provide the first documentation of even-numbered $n$-alkane predominance in northern Gulf of Mexico surface waters. However, it remains unclear whether these even carbon-numbered $n$-alkanes were from biogenic or petroleum sources, which must be differentiated by compound specific isotopic analysis.

Regardless of the exact sources for the $n$-alkanes measured during our study, it is clear that the compositional patterns of $n$-alkanes in 2011 differed markedly from those of 2010 . PCA analysis revealed distinct compositional differences of dissolved $n$-alkanes among the samples from the respective cruises (Fig. 5). An oil mousse sample, collected at Sta. OSS during the oil spill in May 2010 (Liu et al., 2012), was also included for comparison. Principal component 1 (PC1) explained 36\% variance of the data matrix, and PC2 20\% of the remainder variance (Fig. 5). Along the x-axis, samples from May and August 2010 were clearly separated from the May 2011 samples, which were dominated by even-numbered $n$-alkanes from $\mathrm{C}_{14-}-\mathrm{C}_{20}$. May 2010 
samples, enriched with lighter $n$-alkanes $\left(\mathrm{C}_{9}-\mathrm{C}_{13}\right)$, were separated from those of August 2010 along the y-axis. The oil mousse collected at Sta. OSS was heavier than May 2010 samples and resembles the August 2010 samples. Overall, composition of the OSS mousse resembled the May and August 2010 water more than the May 2011 water. The May 2010 samples also contained more abundant pristine $(\mathrm{Pr})$ and phytane $(\mathrm{Ph})$. This grouping pattern provides strong evidence that surface waters in 2010 were contaminated by the $D W H$ oil spill.

The source of petroleum contamination can be traced using the ratio of pristane and phytane ( $\mathrm{Pr} / \mathrm{Ph})($ Volkman et al., 1997). Pr/Ph ratios in May 2010 samples ranged from 0.531.10 (Table 1), and were significantly higher than those of May 2011 (0.30-0.54, $t$-test, $\mathrm{p}=0.02)$. Therefore, the May 2010 samples were much closer to the Macondo source oil and weathered mousses, with $\mathrm{Pr} / \mathrm{Ph}$ ratios ranging from 0.8-1.0 (Liu et al., 2012). These ratios support the argument that the May 2010 surface waters were contaminated by the $D W H$ oil spill.

\subsection{Alkanes in suspended particles}

Concentrations of particulate alkanes $(>0.7 \mu \mathrm{m})$ ranged from 1.2 to $11.7 \mathrm{ng} \mathrm{L}^{-1}$ in the May 2010 samples, with stations OSS and CT having the highest concentrations, 11.1 and 11.7 ng $\mathrm{L}^{-1}$, respectively (Fig. 3b). This pattern, in addition to high $\mathrm{C} / \mathrm{N}$ ratios described above (Fig. 2c), supports the notion that these two stations were contaminated by the oil spill. Oil contamination is further supported by the significantly higher percentages of $n$-alkanes to POC (normalized to carbon) at stations OSS (1.3\%) and CT (0.9\%) than at stations C6, B6 and MRM (0.1-0.4\%, $\mathrm{p}=0.02)$. In August 2010, the concentration of $n$-alkanes was $2.0 \mathrm{ng} \mathrm{L}^{-1}$ at Sta. B6, the only available data from the August 2010 cruise. Concentrations of particulate $n$-alkanes in May 2011 ranged from 0.8-4.3 $\mathrm{n} \mathrm{L}^{-1}$ among all stations but OSS, where the concentration reached $19.2 \mathrm{ng} \mathrm{L}^{-1}$. In general, concentrations of particulate $n$-alkanes did not show as much 
variation as those of dissolved alkanes between 2010 and 2011 samples. This decoupling of particulate and dissolved alkanes suggests that the elevated dissolved alkanes in May 2010 may have been derived directly from surface oil mousse drifting from the accident site to the shores, possibly via dissolution processes. Indeed, water samples from May 2010 during the oil spill were enriched with lighter $n$-alkanes with higher solubility than heavier alkanes (Sutton and Calder, 1974).

Consistent with the concentration data, compositions of particulate alkanes were similar between May 2010 and May 2011 (Fig. S3). However, only at Sta. OSS did the $n$-alkane composition of the particulate phase resemble the dissolved phase, thus suggesting a biogenic source of the even-numbered $n$-alkanes. However, this consistency between dissolved and particulate phase was not observed for other stations. One possible explanation is that the dissolved $n$-alkanes on the shelf originated from regions near Sta. OSS with depths of $100 \mathrm{~m}$, while at other shallower stations ( $<30 \mathrm{~m})$, particulate $n$-alkanes were produced mostly in situ from a variety of different sources. Alternatively, the even-numbered n-alkanes may have been produced by microorganisms that were sustained by oil contaminants in the region adjacent to the DWH accident site (Lu and Meyers, 2009), including the Sta. OSS, and these compounds were transported to the shelf region. More research is needed to decipher this intriguing phenomenon, which is beyond the scope of this study.

Concentrations of $17 \alpha(\mathrm{H}), 21 \beta(\mathrm{H})-30$-hopane, a conservative inert biomarker of petroleum (Prince et al., 1994), ranged from 47-238 $\mathrm{ng} \mathrm{L}^{-1}$ among May 2010 samples, highest at OSS and lowest at C6 (Table 2). In contrast, concentrations in May 2011 ranged from 30-142 ng $\mathrm{L}^{-1}$, highest at MRM. Overall, Sta. OSS had the highest concentration in May $2010\left(238 \mathrm{ng} \mathrm{L}^{-1}\right)$, consistent with the idea that the surface water at this station was contaminated during the $D W H$ 
oil spill. To further investigate the contamination source, the ratio of $17 \alpha(\mathrm{H}), 21 \beta(\mathrm{H})-30$ norhopane over $17 \alpha(\mathrm{H}), 21 \beta(\mathrm{H})$-hopane $\left(\mathrm{C}_{29} / \mathrm{C}_{30}\right)$ was examined (Prince et al., 1994; Wang et al., 2004b). The $\mathrm{C}_{29} / \mathrm{C}_{30}$ ratio of 0.52 measured in the Macondo well oil was consistent with other studies (Carmichael et al., 2012). The $\mathrm{C}_{29} / \mathrm{C}_{30}$ ratios in particles from the OSS and $\mathrm{B} 6$ samples in May 2010 also resembled the source oil (Table 2), providing convincing evidence that the $D W H$ oil spill was indeed the contamination source. In contrast, the ratios of 2011 samples ranged from 0.61-0.84 and deviated substantially from that of the Macondo well oil. It is important to note that the hopanes measured were from water samples without visible oil, so even if samples were contaminated, petroleum hydrocarbons in the samples may be highly weathered, and/or the signal could be diluted by other contamination sources, considering the abundance of oil rigs in this region.

\subsection{PAHs in surface water suspended particles}

PAHs are a group of toxic contaminants that are carcinogenic and mutagenic to humans and wildlife. The $D W H$ oil spill released about $2.1 \times 10^{10} \mathrm{~g}$ PAHs, which represented approximately 3.9\% of the Macondo well oil by weight (Reddy et al., 2011). Particulate PAHs in northern Gulf of Mexico were measured for both May 2010 and May 2011, but dissolved PAHs were measured only for the May 2011 when samples were available. Concentrations of particulate PAHs ranged from 84-252 $\mathrm{ng} \mathrm{L}^{-1}$ in the May 2010 samples and were highest at stations CT and OSS, respectively (228 and $252 \mathrm{ng} \mathrm{L}^{-1}$; Table 1 and Fig. 5). This pattern is consistent with the high concentrations of particulate alkanes and $\mathrm{C} / \mathrm{N}$ ratios at these two stations, all indicating oil contamination. Among the 16 PAHs listed by US EPA, the detectable PAHs included naphthalene, phenanthrene, fluoranthene and pyrene. The dominance of these four types of PAHs is consistent with values measured in the water along the coastal shoreline 
near the accident site (Allan et al., 2012). The PAH composition of these particles is somewhat different from those of surface oil mousses, which were dominated by phenanthrene and chrysene (Liu et al., 2012). This is not surprising, as these PAHs exhibit different solubilities, with compounds dissolved in the water or reattached to suspended particles likely to have lower molecular weights than those associated with oil slicks or mousses.

The levels of particulate PAHs collected in May 2011 were lower than in May 2010, ranging from 7.2-83.3 $\mathrm{ng} \mathrm{L}^{-1}$. This significant decrease of PAHs from 2010 to $2011(p=0.002)$ indicates that weathering processes, such as physical dilution, photochemical reaction and biodegradation, decreased the level of petroleum hydrocarbons in surface waters (Liu and Liu, 2013; Liu et al., 2012). This pattern is consistent with the decreases in dissolved and particulate alkanes from 2010 to 2011 (Fig. 3).

\section{Conclusions and Implications}

Bulk chemical properties, such as POC and DOC, of northern Gulf of Mexico surface waters without visible oil were not measurably altered by the $D W H$ oil spill, when compared to their natural variations. However, multiple lines of evidence show that surface waters in this area were indeed contaminated by petroleum hydrocarbons in May 2010. Concentrations of dissolved alkanes and particulate PAHs were significantly higher in May 2010 than August 2010 and May 2011. Contamination signals, including enhanced hydrocarbon levels and $\mathrm{C} / \mathrm{N}$ ratios as well as diagnostic inert biomarker ratios consistent with Macondo oil, were evident in May 2010 at stations OSS and CT. Also, composition of dissolved alkanes in 2010 resembles the oil mousse more than the dissolved alkanes in 2011. This study is the first to document the dominance of even carbon-numbered dissolved $n$-alkanes $\left(\mathrm{C}_{14}-\mathrm{C}_{20}\right)$ in northern Gulf of Mexico 
surface waters collected in May 2011, and the source of these alkanes seems to be related to microbial activity. Petroleum hydrocarbon levels decreased rapidly during the sequential samplings from May 2010, August 2010, to May 2011, suggesting that the surface oil underwent rapid weathering in warm near-shore coastal waters and/or was rapidly diluted by physical dynamic processes. The data also provide evidence that important quantities of oil contaminants are transported via surface waters even in the absence of noticeable surface oil slicks. 


\section{Acknowledgements}

We thank the crew of the R/V Pelican and Lin X. and Tan Y. for assistance in obtaining samples and taking photos, Kevin Briggs for sharing his August ship time, and David Hirschberg for particulate organic carbon and nitrogen analysis. Comments from Dr. Phil Meyers and another anonymous reviewer greatly improved this manuscript. This work was funded by the National Science Foundation Chemical Oceanography Program (OCE-1042908 to ZL and OCE1042887 to NEO), the National Oceanic and Atmospheric Administration Center for Sponsored Coastal Ocean Research (Grant \# NA07NOS4780225 to WSG), and Gulf Research Initiative (DROPPS Consortium). 


\section{References}

Allan, S.E., Smith, B.W., Anderson, K.A., 2012. Impact of the deepwater horizon oil spill on bioavailable polycyclic aromatic hydrocarbons in Gulf of Mexico coastal waters. Environ Sci Technol 46, 2033-2039.

Benner, R., Opsahl, S., 2001. Molecular indicators of the sources and transformations of dissolved organic matter in the Mississippi river plume. Org Geochem 32, 597-611.

Bianchi, T.S., DiMarco, S.F., Smith, R.W., Schreiner, K.M., 2009. A gradient of dissolved organic carbon and lignin from Terrebonne-Timbalier Bay estuary to the Louisiana shelf (USA). Marine Chemistry 117, 32-41.

Camilli, R., Reddy, C.M., Yoerger, D.R., Van Mooy, B.A.S., Jakuba, M.V., Kinsey, J.C., McIntyre, C.P., Sylva, S.P., Maloney, J.V., 2010. Tracking Hydrocarbon Plume Transport and Biodegradation at Deepwater Horizon. Science 330, 201-204.

Carmichael, C.A., Arey, J.S., Graham, W.M., Linn, L.J., Lemkau, K.L., Nelson, R.K., Reddy, C.M., 2012. Floating oil-covered debris from Deepwater Horizon: Identification and application. Environ. Res. Lett. 7, 015301.

Colombo, J.C., Pelletier, E., Brochu, C., Khalil, M., Catoggio, J.A., 1989. Determination of hydrocarbon sources using $n$-alkane and polyaromatic hydrocarbon distribution indexes. Case study: Rio de La Plata estuary, Argentina. Environ Sci Technol 23, 888-894.

Cowan, J.H., Grimes, C.B., Shaw, R.F., 2008. Life history, history, hysteresis, and habitat changes in Louisiana's coastal ecosystem. Bulletin of Marine Science 83, 197-215.

Crone, T.J., Tolstoy, M., 2010. Magnitude of the 2010 Gulf of Mexico oil leak. Science 330, 634-634.

Dagg, M., Benner, R., Lohrenz, S., Lawrence, D., 2004. Transformation of dissolved and particulate materials on continental shelves influenced by large rivers: plume processes. Cont. Shelf Res. 24, 833-858.

Dagg, M.J., Ammerman, J.W., Amon, R.M.W., Gardner, W.S., Green, R.E., Lohrenz, S.E., 2007. A review of water column processes influencing hypoxia in the northern Gulf of Mexico. Estuar Coast 30, 735-752.

Dagg, M.J., Breed, G.A., 2003. Biological effects of Mississippi River nitrogen on the northern Gulf of Mexico - a review and synthesis. J Marine Syst 43, 133-152.

Edwards, B.R., Reddy, C.M., Camilli, R., Carmichael, C.A., Longnecker, K., Van Mooy, B.A.S., 2011. Rapid microbial respiration of oil from the Deepwater Horizon spill in offshore surface waters of the Gulf of Mexico. Environ. Res. Lett. 6.

Elias, V.O., Simoneit, B.R., Cardoso, J.N., 1997. Even $n$-alkane predominances on the Amazon shelf and a Northeast Pacific hydrothermal system. Naturwissenschaften 84, 415-420.

Fingas, M.F., 1999. The evaporation of oil spills: development and implementation of new prediction methodology, International Oil Spill Conference. Environmental Protection Agency, Seattle.

Graham, W.M., Condon, R.H., Carmichael, R.H., D'Ambra, I., Patterson, H.K., Linn, L.J., Hernandez, F.J., 2010. Oil carbon entered the coastal planktonic food web during the Deepwater Horizon oil spill. Environ. Res. Lett. 5.

Grimalt, J., Albaigés, J., 1987. Sources and occurrence of $\mathrm{C}_{12}-\mathrm{C}_{22}$-alkane distributions with even carbon-number preference in sedimentary environments. Geochim Cosmochim Ac 51, 1379-1384. 
Guo, L.D., White, D.M., Xu, C., Santschi, P.H., 2009. Chemical and isotopic composition of high-molecular-weight dissolved organic matter from the Mississippi River plume. Mar Chem 114, 63-71.

Hardy, J.T., Crecelius, E.A., Antrim, L.D., Kiesser, S.L., Broadhurst, V.L., Boehm, P.D., Steinhauer, W.G., Coogan, T.H., 1990. Aquatic source microlayer contamination in Chesapeake Bay. Marine Chemistry 28, 333-351.

Hazen, T.C., Dubinsky, E.A., DeSantis, T.Z., Andersen, G.L., Piceno, Y.M., Singh, N., Jansson, J.K., Probst, A., Borglin, S.E., Fortney, J.L., Stringfellow, W.T., Bill, M., Conrad, M.E., Tom, L.M., Chavarria, K.L., Alusi, T.R., Lamendella, R., Joyner, D.C., Spier, C., Baelum, J., Auer, M., Zemla, M.L., Chakraborty, R., Sonnenthal, E.L., D'Haeseleer, P., Holman, H.Y.N., Osman, S., Lu, Z.M., Van Nostrand, J.D., Deng, Y., Zhou, J.Z., Mason, O.U., 2010. Deep-sea oil plume enriches indigenous oil-degrading bacteria. Science 330, 204-208.

Hebrard, G., Zeng, J., Loubiere, K., 2009. Effect of surfactants on liquid side mass transfer coefficients: A new insight. Chem Eng J 148, 132-138.

Hu, L.M., Guo, Z.G., Feng, J.L., Yang, Z.S., Fang, M., 2009. Distributions and sources of bulk organic matter and aliphatic hydrocarbons in surface sediments of the Bohai Sea, China. Marine Chemistry 113, 197-211.

Hunt, J.M., 1996. Petroleum geochemistry and geology, 2nd ed. W.H. Freeman, New York.

Incardona, J.P., Collier, T.K., Scholz, N.L., 2004. Defects in cardiac function precede morphological abnormalities in fish embryos exposed to polycyclic aromatic hydrocarbons. Toxicology and applied pharmacology 196, 191-205.

Jones, J.G., Young, B.V., 1970. Major paraffin constituents of microbial cells with particular references to Chromatium sp. Arch Mikrobiol 70, 82-88.

Joye, S.B., MacDonald, I.R., Leifer, I., Asper, V., 2011. Magnitude and oxidation potential of hydrocarbon gases released from the BP oil well blowout. Nat. Geosci. 4, 160-164.

Kessler, J.D., Valentine, D.L., Redmond, M.C., Du, M.R., Chan, E.W., Mendes, S.D., Quiroz, E.W., Villanueva, C.J., Shusta, S.S., Werra, L.M., Yvon-Lewis, S.A., Weber, T.C., 2011. A persistent oxygen anomaly reveals the fate of spilled methane in the deep Gulf of Mexico. Science 331, 312-315.

Kostka, J.E., Prakash, O., Overholt, W.A., Green, S.J., Freyer, G., Canion, A., Delgardio, J., Norton, N., Hazen, T.C., Huettel, M., 2011. Hydrocarbon degrading bacteria and the bacterial community response in Gulf of Mexico beach sands impacted by the Deepwater Horizon oil spill. Appl Environ Microb 77, 7962-7974.

Kujawinski, E.B., Kido Soule, M.C., Valentine, D.L., Boysen, A.K., Longnecker, K., Redmond, M.C., 2011. Fate of dispersants associated with the Deepwater Horizon oil spill. Environ Sci Technol 45, 1298-1306.

Leifer, B.e.a., 2010. Deepwater Horizon Release Estimate of Rate by PIV, in: Interior, U.D.o. (Ed.).

Lin, X., McCarthy, M.J., Carini, S.A., Gardner, W.S., 2011. Net, actual, and potential sedimentwater interface NH4+ fluxes in the northern Gulf of Mexico (NGOMEX): Evidence for NH4+ limitation of microbial dynamics. Cont. Shelf Res. 31, 120-128.

Liu, Z., Breecker, D., Mayer, L.M., Zhong, J., 2013. Composition of size-fractioned sedimentary organic matter in coastal environments is affected by difference in physical forcing strength. Org Geochem 60, 20-32. 
Liu, Z., Liu, J., 2013. Evaluating bacterial community structures in oil collected from the sea surface and sediment in the northern Gulf of Mexico after the Deepwater Horizon oil spill. MicrobiologyOpen.

Liu, Z., Liu, J., Zhu, Q., Wu, W., 2012. The weathering of oil after the Deepwater Horizon oil spill: insights from the chemical composition of the oil from the sea surface, salt marshes and sediments. Environ. Res. Lett. 7, 035302.

Liu, Z.F., Stewart, G., Cochran, J.K., Lee, C., Armstrong, R.A., Hirschberg, D.J., Gasser, B., Miquel, J.C., 2005. Why do POC concentrations measured using Niskin bottle collections sometimes differ from those using in-situ pumps? Deep-Sea Res Pt I 52, 1324-1344.

Lohrenz, S.E., Redalje, D.G., Cai, W.J., Acker, J., Dagg, M., 2008. A retrospective analysis of nutrients and phytoplankton productivity in the Mississippi River plume. Cont. Shelf Res. 28, 1466-1475.

Lu, Y.H., Meyers, P.A., 2009. Sediment lipid biomarkers as recorders of the contamination and cultural eutrophication of Lake Erie, 1909-2003. Org Geochem 40, 912-921.

Mackay, D., 1982. Effects of Surface Films on Air-Water Exchange Rates. J Great Lakes Res 8, 299-306.

Meglen, R.R., 1992. Examing large databases: A chemometric approaching using principal component analysis. Marine Chemistry 39, 217-237.

Meyers, P.A., 1997. Organic geochemical proxies of paleoceanographic, paleolimnologic, and paleoclimatic processes. Org Geochem 27, 213-250.

Nishimura, M., Baker, E.W., 1986. Possible origin of $n$-alkanes with a remarkable even-to-odd predominance in recent marine sediments. Geochim Cosmochim Ac 50, 299-305.

Pakulski, J.D., Benner, R., Whitledge, T., Amon, R., Eadie, B., Cifuentes, L., Ammerman, J., Stockwell, D., 2000. Microbial metabolism and nutrient cycling in the Mississippi and Atchafalaya River plumes. Estuar Coast Shelf S 50, 173-184.

Plata, D.L., Sharpless, C.M., Reddy, C.M., 2008. Photochemical degradation of polycyclic aromatic hydrocarbons in oil films. Environ Sci Technol 42, 2432-2438.

Pomeroy, L.R., Sheldon, J.E., Sheldon, W.M., Peters, F., 1995. Limits to growth and respiration of bacterioplankton in the Gulf of Mexico. Mar Ecol-Prog Ser 117, 259-268.

Prince, R.C., Elmendorf, D.L., Lute, J.R., Hsu, C.S., Haith, C.E., Senius, J.D., Dechert, G.J., Douglas, G.S., Butler, E.L., 1994. 17. alpha.(H)-21. beta.(H)-hopane as a conserved internal marker for estimating the biodegradation of crude oil. Environ Sci Technol 28, 142-145.

Rabalais, N.N., 2011. Troubled waters of the gulf of mexico. Oceanography 24, 200.

Rabalais, N.N., Diaz, R.J., Levin, L.A., Turner, R.E., Gilbert, D., Zhang, J., 2010. Dynamics and distribution of natural and human-caused hypoxia. Biogeosciences 7, 585-619.

Rabalais, N.N., Turner, R.E., Dortch, Q., Justic, D., Bierman, V.J., Wiseman, W.J., 2002. Nutrient-enhanced productivity in the northern Gulf of Mexico: past, present and future. Hydrobiologia 475, 39-63.

Reddy, C.M., Arey, J.S., Seewald, J.S., Sylva, S.P., Lemkau, K.L., Nelson, R.K., Carmichael, C.A., McIntyre, C.P., Fenwick, J., Ventura, G.T., 2011. Composition and fate of gas and oil released to the water column during the Deepwater Horizon oil spill. Proceedings of the National Academy of Sciences.

Ryerson, T.B., Camilli, R., Kessler, J.D., Kujawinski, E.B., Reddy, C.M., Valentine, D.L., Atlas, E., Blake, D.R., de Gouw, J., Meinardi, S., 2012. Chemical data quantify Deepwater 
Horizon hydrocarbon flow rate and environmental distribution. Proceedings of the National Academy of Sciences 109, 20246-20253.

Schenck, P.A., Havenaar, I., Geochemical Society. Organic Geochemistry Group. European Branch., 1969. Advances in organic geochemistry, 1968; proceedings, 1st ed. Pergamon Press, Oxford, New York,.

Shank, G.C., Evans, A., 2011. Distribution and photoreactivity of chromophoric dissolved organic matter in northern Gulf of Mexico shelf waters. Cont. Shelf Res. 31, 1128-1139.

Short, J.W., Harris, P.M., 1996. Chemical sampling and analysis of petroleum hydrocarbons in the near-surface seawater of Prince William Sound after the Exxon Valdez oil spill, in: Rice, S.D., Spies, R.B., Wolfe, D.A., Wright, B.A. (Eds.), Proceedings Of The Exxon Valdez Oil Spill Symposium. American Fisheries Society, Bethesda, Maryland, pp. 1728.

Simoneit, B.R., 1977. Diterpenoid compounds and other lipids in deep-sea sediments and their geochemical significance. Geochim Cosmochim Ac 41, 463-476.

Stortini, A.M., Martellini, T., Del Bubba, M., Lepri, L., Capodaglio, G., Cincinelli, A., 2009. nAlkanes, PAHs and surfactants in the sea surface microlayer and sea water samples of the Gerlache Inlet sea (Antarctica). Microchemical Journal 92, 37-43.

Sutton, C., Calder, J.A., 1974. Solubility of higher molecular weight n-paraffins in distilled water and seawater. Environ Sci Technol 8, 654-657.

Valentine, D.L., Kessler, J.D., Redmond, M.C., Mendes, S.D., Heintz, M.B., Farwell, C., Hu, L., Kinnaman, F.S., Yvon-Lewis, S., Du, M.R., Chan, E.W., Tigreros, F.G., Villanueva, C.J., 2010. Propane Respiration Jump-Starts Microbial Response to a Deep Oil Spill. Science 330, 208-211.

Volkman, J.K., Revill, A.T., Murray, A.P., 1997. Applications of biomarkers for identifying sources of natural and pollutant hydrocarbons in aquatic environments, Acs Sym Ser. ACS Publications, pp. 110-132.

Wang, X.C., Chen, R.F., Gardner, G.B., 2004a. Sources and transport of dissolved and particulate organic carbon in the Mississippi River estuary and adjacent coastal waters of the northern Gulf of Mexico. Marine Chemistry 89, 241-256.

Wang, Z.D., Fingas, M., Lambert, P., Zeng, G., Yang, C., Hollebone, B., 2004b. Characterization and identification of the Detroit River mystery oil spill (2002). J Chromatogr A 1038, 201-214.

Wang, Z.D., Fingas, M., Page, D.S., 1999. Oil spill identification. J Chromatogr A 843, 369-411.

Wang, Z.D., Fingas, M.F., 2003. Development of oil hydrocarbon fingerprinting and identification techniques. Mar Pollut Bull 47, 423-452.

Wysocki, L.A., Bianchi, T.S., Powell, R.T., Reuss, N., 2006. Spatial variability in the coupling of organic carbon, nutrients, and phytoplankton pigments in surface waters and sediments of the Mississippi River plume. Estuar Coast Shelf S 69, 47-63.

Yunker, M.B., Macdonald, R.W., Veltkamp, D.J., Cretney, W.J., 1995. Terrestrial and marine biomarkers in a seaonsally ice-covered Arctic estuary: Integration of multivariate and biomarker approaches. Mar Chem 49, 1-50. 
Table 1. Physical and chemical parameters at sampling stations in the northern Gulf of Mexico during May 20-27 and August 3-10 2010, and May 19-25 , 2011. The stations are listed in the order of their distances to the DH wellhead.

\begin{tabular}{|c|c|c|c|c|c|c|c|c|c|c|c|c|c|c|c|c|c|}
\hline Stations & $\begin{array}{l}\text { Distance } \\
\text { to the } \\
\text { well }(\mathrm{km})\end{array}$ & *Salinity & $\begin{array}{l}{ }^{*} \text { Temp } \\
\left({ }^{\circ} \mathrm{C}\right)\end{array}$ & $\begin{array}{c}{ }^{*} \mathrm{DO} \\
\left(\mathrm{mg} \mathrm{L}^{-1}\right)^{@}\end{array}$ & ${ }^{*}$ Fluor & $\begin{array}{l}\mathrm{NO}_{3} \\
(\mu \mathrm{M})\end{array}$ & $\begin{array}{l}\mathrm{DOC} \\
(\mu \mathrm{M})\end{array}$ & $\begin{array}{l}\mathrm{POC} \\
(\mu \mathrm{M})\end{array}$ & $\begin{array}{l}\mathrm{PN} \\
(\mu \mathrm{M})\end{array}$ & $\mathrm{C} / \mathrm{N}$ & $\begin{array}{c}\text { Dissolved } \\
\text { alkanes } \\
\left(\mu \mathrm{g} \mathrm{L}^{-1}\right)\end{array}$ & $\begin{array}{c}\text { Particulate } \\
\text { alkanes } \\
\left(\mu \mathrm{g} \mathrm{L}^{-1}\right)\end{array}$ & $\begin{array}{c}\text { Particulate } \\
\text { PAHs } \\
\left(\mathrm{ng} \mathrm{L}^{-1}\right)\end{array}$ & $\begin{array}{c}\mathrm{pr} / \mathrm{ph}^{\&} \\
\text { (dissol } \\
\text { ved) }\end{array}$ & 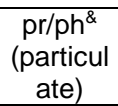 & $\begin{array}{c}\mathrm{CPI}^{\#} \\
\text { (dissolve } \\
\text { d) }\end{array}$ & $\begin{array}{c}\mathrm{CPI}^{\#} \\
\text { (particul } \\
\text { ate) }\end{array}$ \\
\hline $\mathrm{F}^{\mathrm{a}}$ & 317 & 34.3 & 26.5 & $6.61(100 \%)$ & 0.04 & 1.18 & 95.8 & 10.7 & 1.5 & 7.1 & 110 & -- & -- & 1.10 & -- & 1.61 & -- \\
\hline$C 6^{\mathrm{a}}$ & 203 & 28.3 & 27.1 & $8.74(129 \%)$ & 0.36 & 1.33 & 238 & 88.0 & 9.9 & 8.9 & 142 & 1.2 & 83.5 & 0.53 & 1.60 & 2.27 & 1.16 \\
\hline$B 6^{\mathrm{a}}$ & 167 & 14.3 & 27.6 & $8.20(112 \%)$ & 0.37 & 25.2 & 204 & 91.8 & 15.3 & 6.0 & -- & 3.4 & 178 & -- & 0.66 & -- & 1.46 \\
\hline $\mathrm{MRM}^{\mathrm{a}}$ & 106 & 6.7 & 26.1 & $6.13(79 \%)$ & 0.34 & 78.2 & 250 & 122.7 & 9.7 & 12.6 & 85.8 & 6.2 & 214 & 0.66 & 0.78 & 1.79 & 1.48 \\
\hline $\mathrm{CT}^{\mathrm{a}}$ & 238 & 23.4 & 28.4 & $8.35(122 \%)$ & 0.39 & ND & 179 & 84.7 & 7.7 & 11 & -- & 11.1 & 228 & -- & 0.64 & -- & 1.17 \\
\hline OSS $^{a}$ & 133 & 28.6 & 28.7 & $8.54(77 \%)$ & 0.20 & ND & 167 & 63.6 & 6.6 & 9.6 & 94.5 & 11.7 & 252 & 0.80 & 0.63 & 1.46 & 1.40 \\
\hline $\mathrm{F} 5^{\mathrm{b}}$ & 317 & 21.6 & 32.5 & $7.05(109 \%)$ & 0.12 & ND & 267 & 83.9 & 11.5 & 7.3 & 3.5 & -- & -- & ND & -- & 1.96 & -- \\
\hline $\mathrm{C} 6^{\mathrm{b}}$ & 203 & 27.7 & 31.9 & $6.43(102 \%)$ & 0.07 & ND & 192 & 32.0 & 3.2 & 10 & 2.7 & -- & -- & ND & -- & 2.91 & -- \\
\hline $\mathrm{B} 6^{\mathrm{b}}$ & 167 & 26.0 & 31.8 & $6.05(95 \%)$ & 0.32 & ND & 317 & 81.2 & 11.6 & 7.0 & 3.5 & 2.0 & 55.7 & ND & 0.44 & 1.43 & 1.51 \\
\hline $\mathrm{MRM}^{\mathrm{b}}$ & 106 & 22.6 & 31.7 & $4.83(74 \%)$ & 0.32 & ND & 225 & 257 & 22.4 & 11.5 & -- & -- & -- & ND & 0.95 & -- & 2.18 \\
\hline $\mathrm{CT}^{\mathrm{b}}$ & 238 & 27.5 & 31.6 & $6.31(96 \%)$ & 0.09 & ND & 250 & 40.7 & 5.4 & 7.5 & 4.2 & -- & -- & ND & 0.86 & 1.86 & 2.18 \\
\hline OSS $^{b}$ & 133 & 28.6 & 31.1 & $6.12(94 \%)$ & 0.07 & ND & 183 & 29.6 & 4.3 & 6.9 & 9.4 & -- & -- & ND & -- & 1.96 & -- \\
\hline$F 5^{c}$ & 317 & 33.6 & 24.2 & $6.68(97 \%)$ & 0.04 & 0.55 & 125 & -- & -- & -- & 28.9 & -- & -- & 0.30 & -- & 0.12 & -- \\
\hline $\mathrm{C} 6^{\mathrm{C}}$ & 203 & 26.9 & 24.4 & $7.40(103 \%)$ & 0.04 & 4.73 & 208 & -- & -- & -- & 10.8 & 4.3 & 7.2 & 0.43 & 0.88 & 0.18 & 1.78 \\
\hline $\mathrm{B} 6^{\mathrm{C}}$ & 167 & 33.6 & 24.2 & $6.68(97 \%)$ & 0.06 & 2.22 & 200 & -- & -- & -- & 30.0 & 0.8 & 22.0 & 0.54 & 1.26 & 0.25 & 1.11 \\
\hline $\mathrm{MRM}^{\mathrm{c}}$ & 106 & 9.9 & 25.1 & $7.46(96 \%)$ & 0.12 & 25.35 & 283 & -- & -- & -- & -- & 3.5 & 25.7 & -- & 0.80 & -- & 1.50 \\
\hline $\mathrm{CT}^{\mathrm{c}}$ & 238 & 26.8 & 24.9 & $8.45(119 \%)$ & 0.06 & 4.31 & 183 & -- & -- & -- & 34.7 & 2.5 & 83.3 & 0.48 & 0.69 & 0.16 & 1.08 \\
\hline OSS $^{c}$ & 133 & -- & -- & -- & -- & -- & -- & -- & -- & -- & 24.8 & 19.2 & 62.1 & 0.35 & 0.48 & 0.11 & 3.34 \\
\hline
\end{tabular}

*Salinity, Temperature (Temp), dissolved oxygen (DO), and fluorescence (Fluor) data are collected by the CTD at depths of $0.2 \mathrm{~m}$. At each station, the data are averaged from about 10 or more data points, and the relative standard deviations are less than $1 \%$. The fluorescence (Fluor) sensor was tuned to chlorophyll a, but not calibrated, so the data only provides a relative comparison of phytoplankton biomass among the stations.

${ }^{\circledR}$ The percentages after the DO concentrations represent the saturation degrees.

\&Ratio of pristane (pr) over phytane (ph)

\#The CPIs of dissolved n-alkanes were calculated using the equation: $\mathrm{CPI}=\left(\mathrm{C}_{23}+\mathrm{C}_{25}+\mathrm{C}_{27}+\mathrm{C}_{29}+\mathrm{C}_{31}+\mathrm{C}_{33}\right) /\left(\mathrm{C}_{24}+\mathrm{C}_{26}+\mathrm{C}_{28}+\mathrm{C}_{30}+\mathrm{C}_{32}+\mathrm{C}_{34}\right)$. $\mathrm{C}_{23-34}$ represents n-alkanes. ND: not detected.

-- no data due to either not sampled or sample loss during the sample pretreatment. 
Table 2. Concentrations of $17 \alpha(\mathrm{H}), 21 \beta(\mathrm{H})$-hopane $(\mathrm{H})$ in surface particulate samples collected among different cruises. The ratios of $17 \alpha(\mathrm{H}), 21 \beta(\mathrm{H})-30$-norhopane over $17 \alpha(\mathrm{H}), 21 \beta(\mathrm{H})$ hopane $\left(\mathrm{C}_{29} / \mathrm{C}_{30}\right)$ was also calculated.

\begin{tabular}{lrc}
\hline Station & $\mathrm{C}_{30}\left(\mathrm{ng} \mathrm{L}^{-1}\right)$ & $\mathrm{C}_{29} / \mathrm{C}_{30}$ \\
\hline MRM $^{\mathrm{a}}$ & 188 & 0.77 \\
$\mathrm{C6}^{\mathrm{a}}$ & 47.6 & 0.71 \\
$\mathrm{OSS}^{\mathrm{a}}$ & 238 & 0.50 \\
$\mathrm{B6}^{\mathrm{a}}$ & 129 & 0.53 \\
$\mathrm{B6}^{\mathrm{b}}$ & 35.3 & 0.60 \\
$\mathrm{MRM}^{\mathrm{c}}$ & 142 & 0.75 \\
$\mathrm{CT}^{\mathrm{c}}$ & 108 & 0.84 \\
$\mathrm{C6}^{\mathrm{c}}$ & 80.4 & 0.58 \\
OSS $^{\mathrm{c}}$ & 104 & 0.71 \\
$\mathrm{~B}^{\mathrm{c}}$ & 30.3 & 0.61 \\
Macondo oil & $64.5 \pm 6.5^{\mathrm{d}}$ & 0.52 \\
\hline
\end{tabular}

${ }^{\mathrm{a}}$ May 2010; ${ }^{\mathrm{b}}$ August 2010; ${ }^{\mathrm{c}}$ May 2011; ${ }^{\mathrm{d}} \mathrm{mg} \mathrm{kg}^{-1}$ 


\section{Figure Captions}

Figure 1. Sampling stations in the northern Gulf of Mexico. The 6 stations were sampled during three cruises from May 20-27 2010, August 3-10, 2010, and May 19-25, 2011.

Figure 2. Relationships between salinity and (a) DOC, and (b) POC in surface waters of the 6 stations sampled in May and August, 2010. The linear regression line (mixing line) is based on the data from three stations. The elevated DOC values above the mixing line illustrate the midsalinity production. (c) Atomic $\mathrm{C} / \mathrm{N}$ ratios of suspended particles collected in May and August 2010 at each station.

Figure 3. Concentrations of (a) dissolved and (b) particulate $n$-alkanes in samples collected in May and August 2010, and May 2011 at each station.

Figure 4. Concentrations of dissolved $n$-alkanes at Sta. C6 in (a) May 2010, and (b) May 2011. Error bar represented one standard deviation of duplicate samples.

Figure 5. Principal component analysis (PCA) on dissolved alkanes from samples collected in May 2010 (5.2010), August 2010 (8.2010), and May 2011 (5.2011). Data from a mousse sample collected at Sta. OSS in May 2010 were also included (Liu et al., 2012). The $n$-alkanes, pristane $(\mathrm{Pr})$ and phytane $(\mathrm{Ph})$ were normalized to weight percentages for the PCA. The principal component 1 (PC1) along the $\mathrm{x}$-axis explains $36 \%$ of the total variance of the data set, and the PC 2 along the $y$-axis explains $21 \%$ of the total variance. These 2011 samples (solid circles in the figure) are separated due to the dominance of even carbon-numbered n-alkanes $\left(\mathrm{C}_{14}-\mathrm{C}_{20}\right)$. 
Figure 1

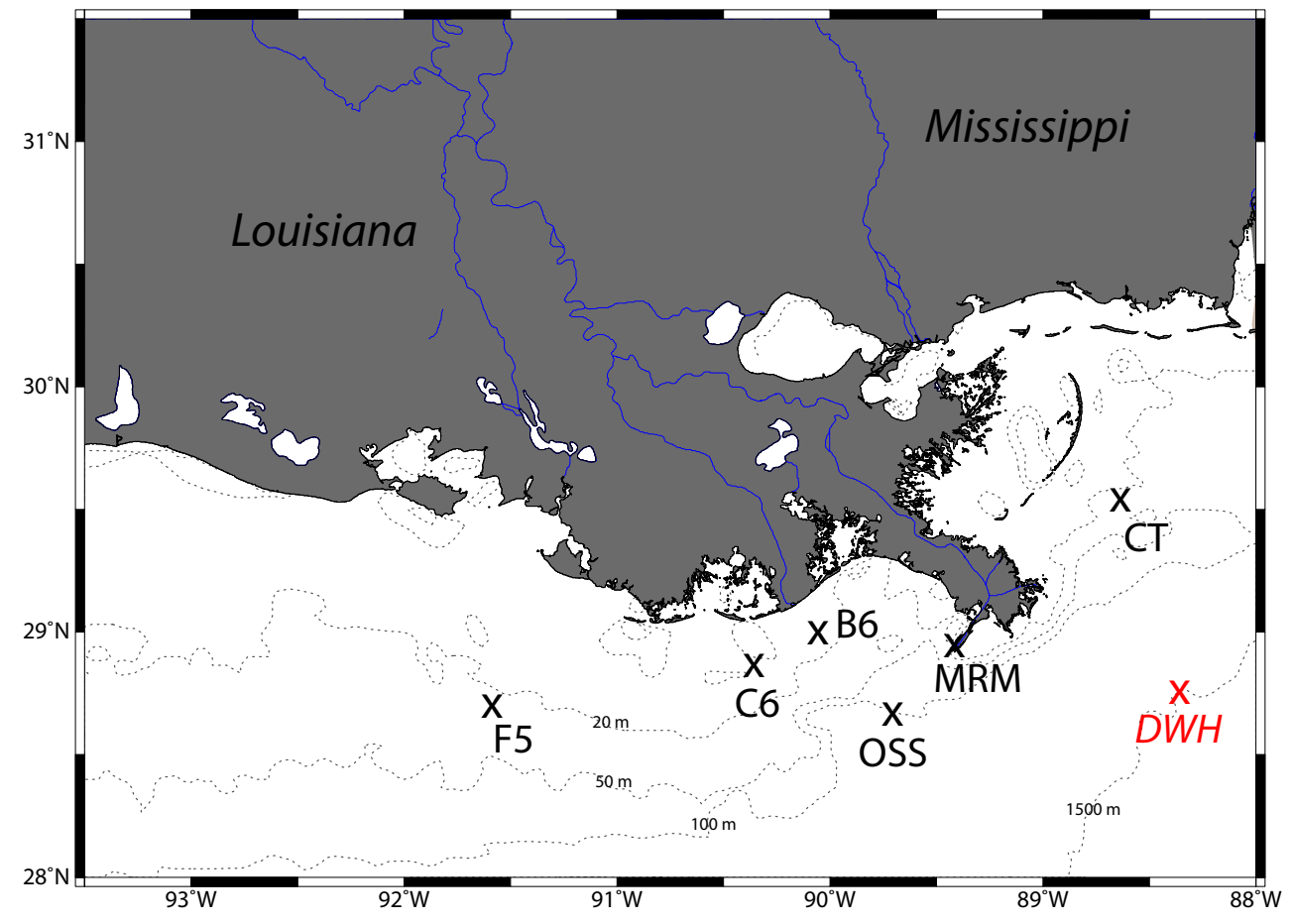


Figure 2
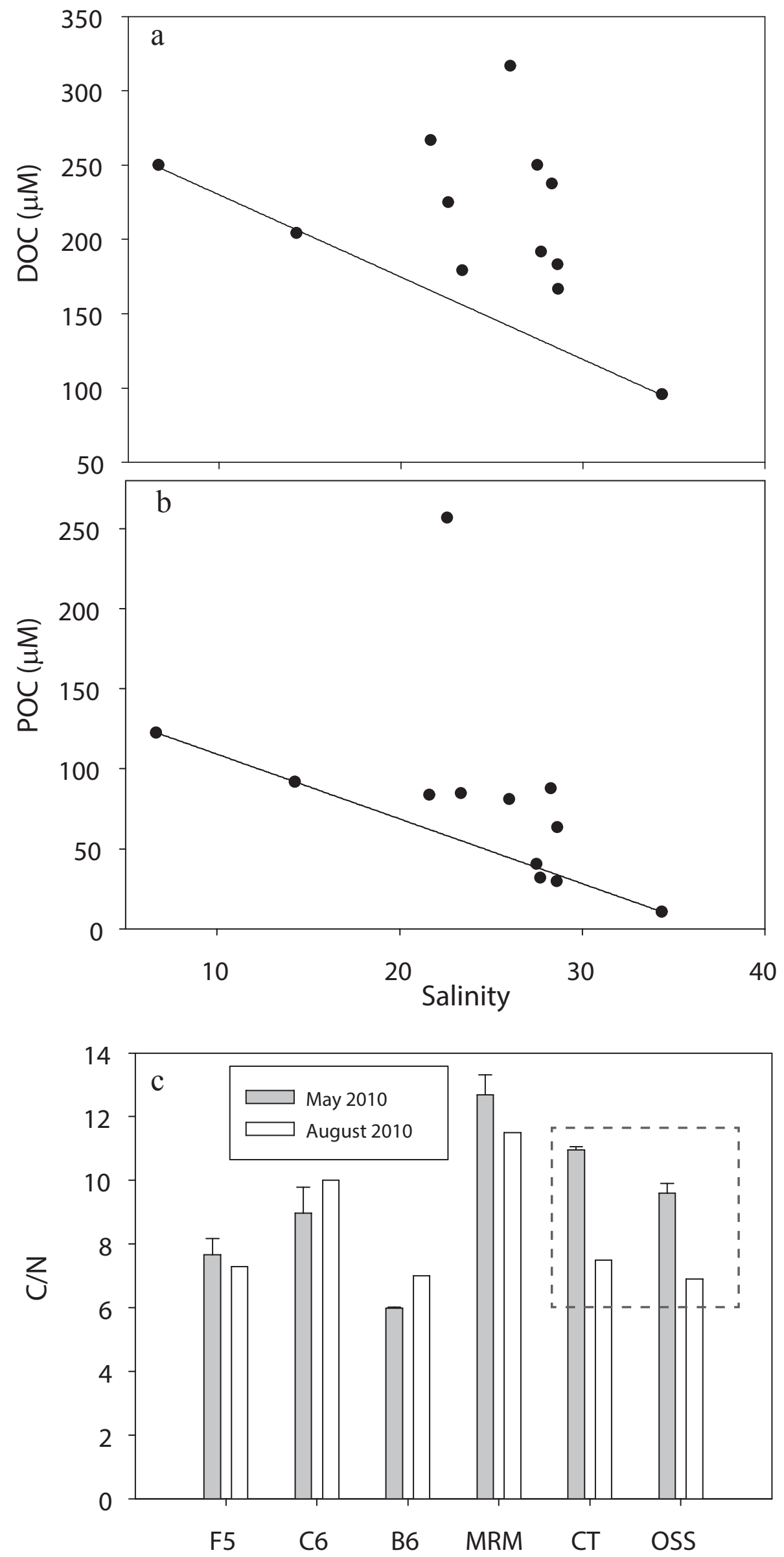
Figure 3
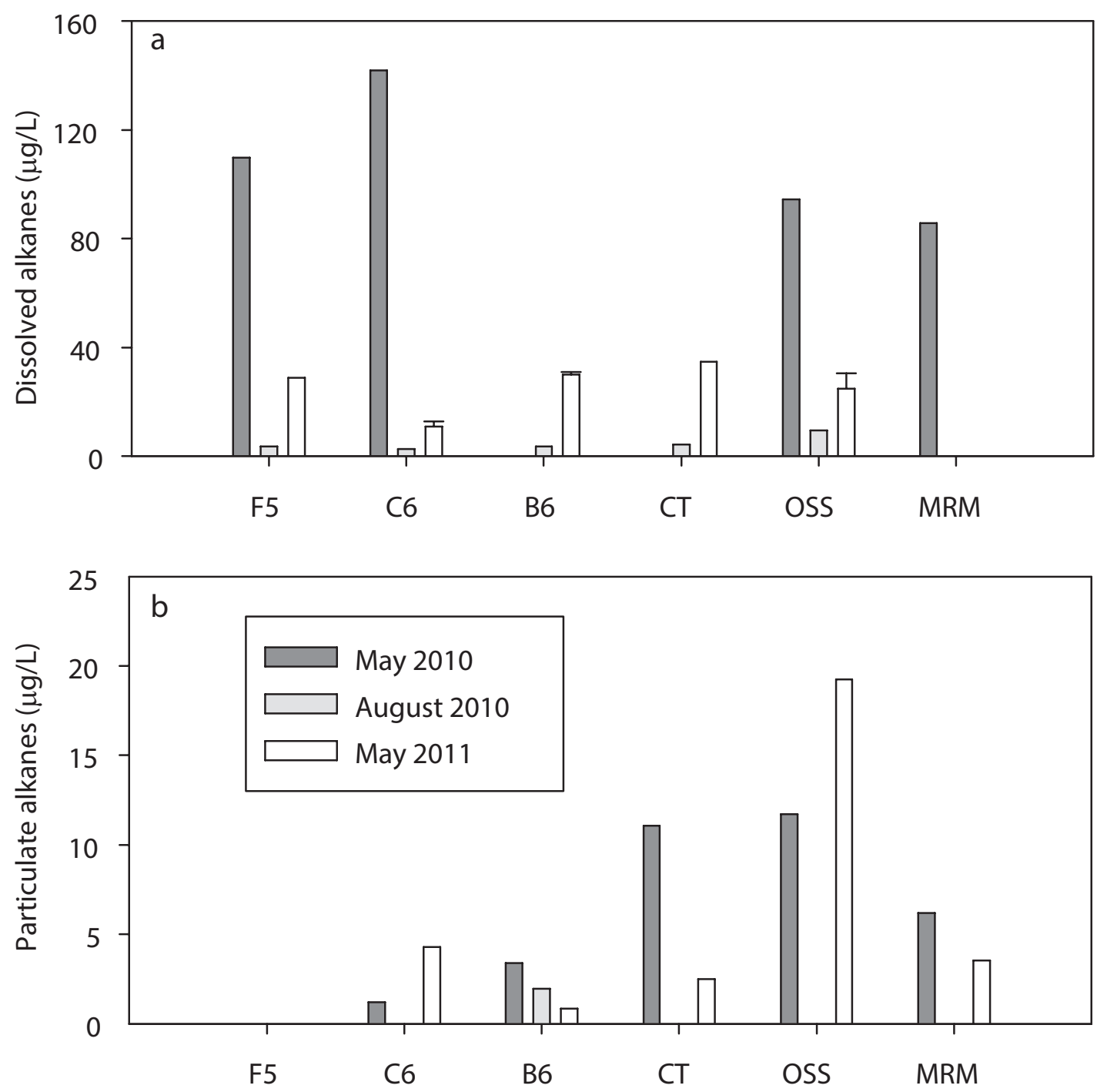
Figure 4
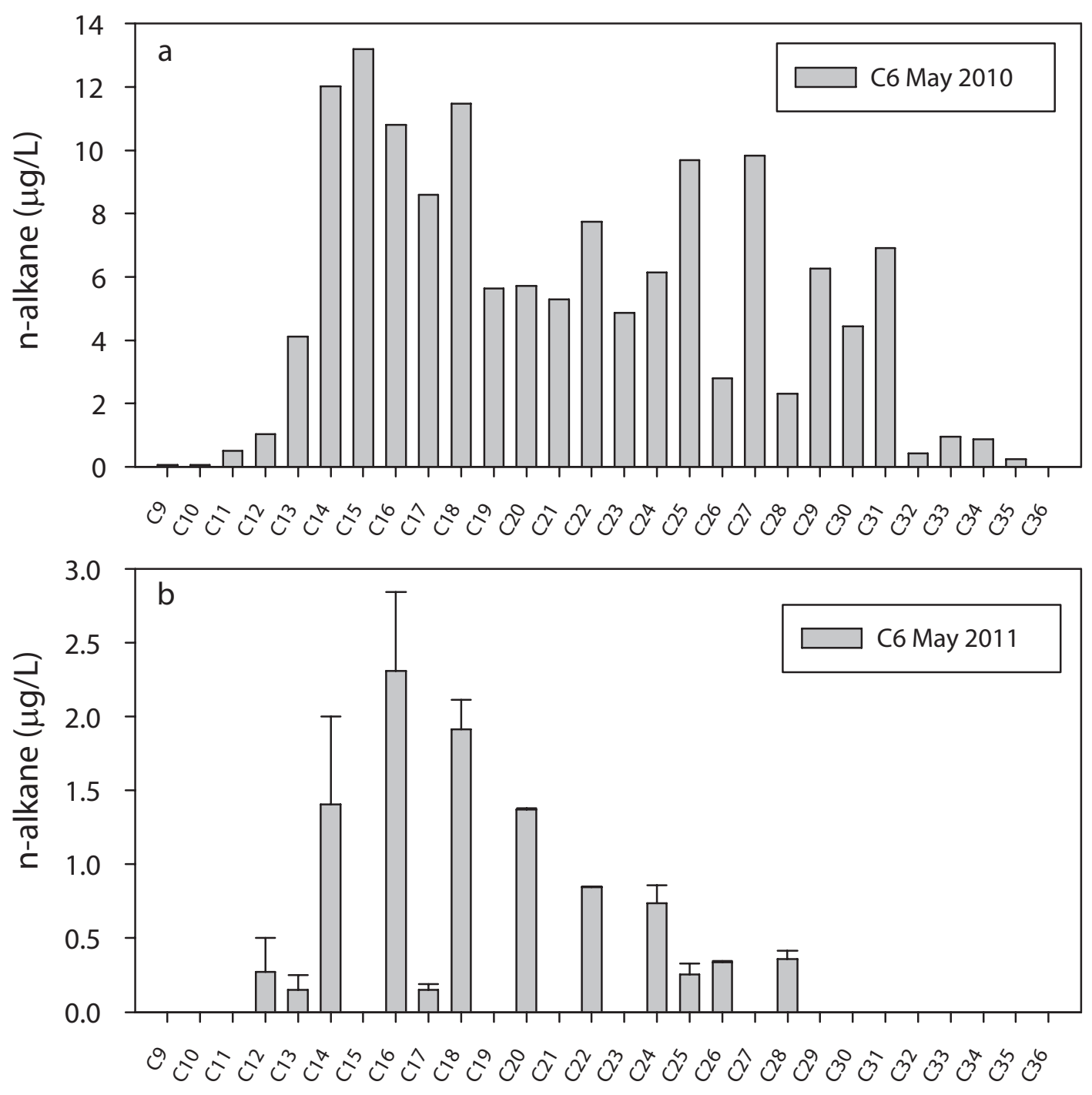
Figure 5

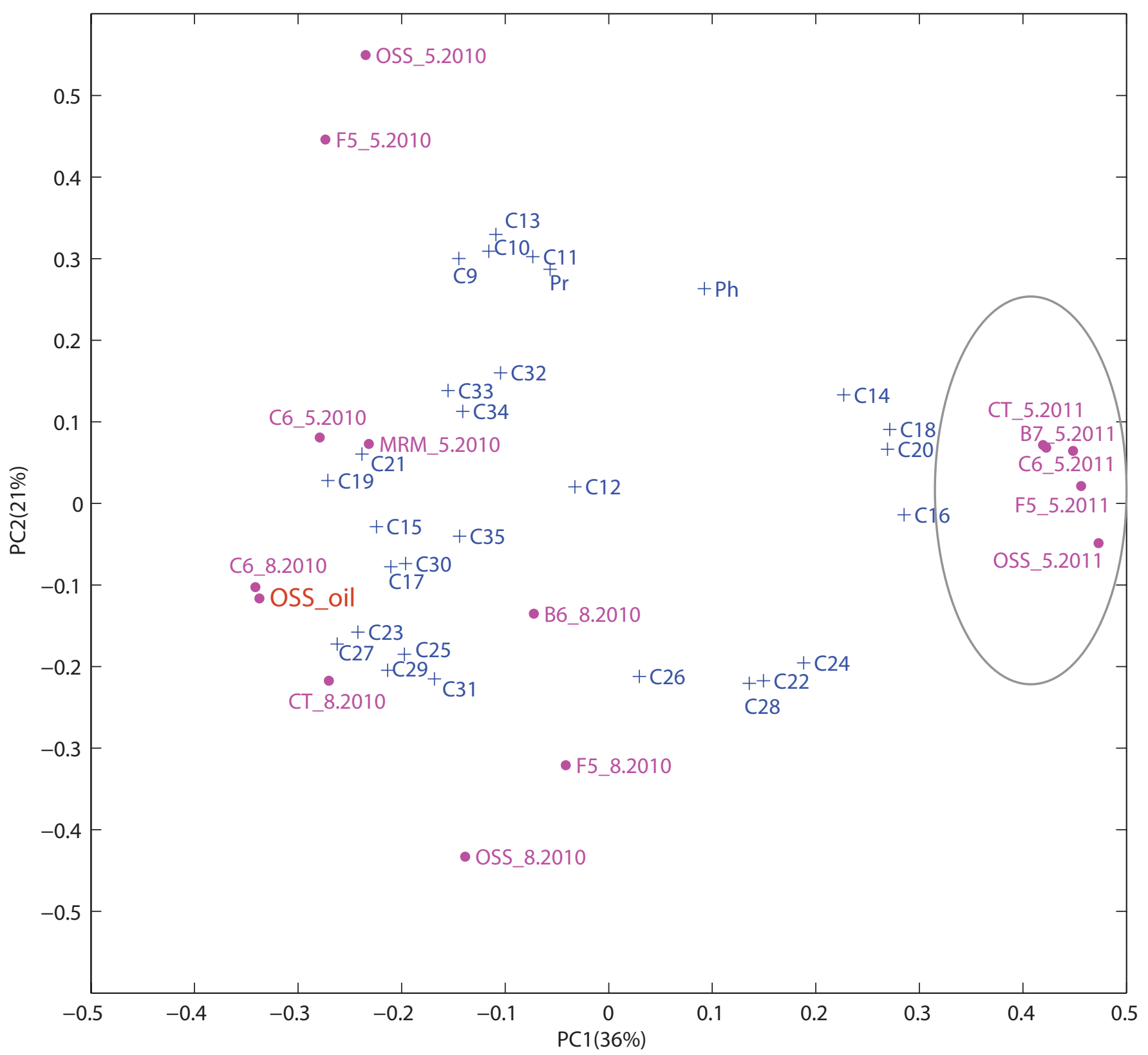


a. May 2010

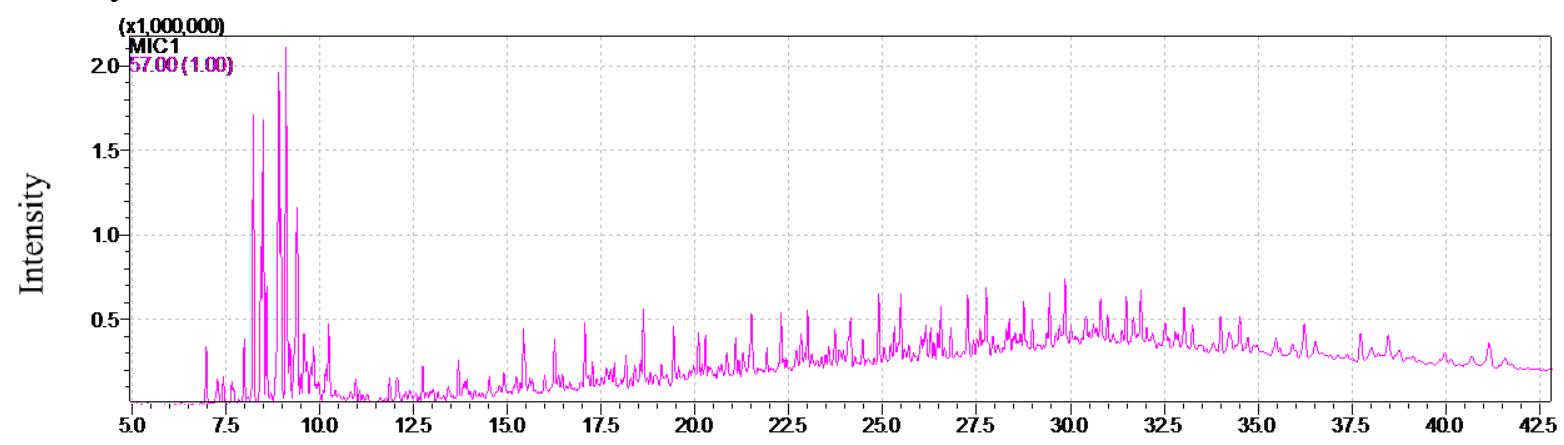

b. May 2011

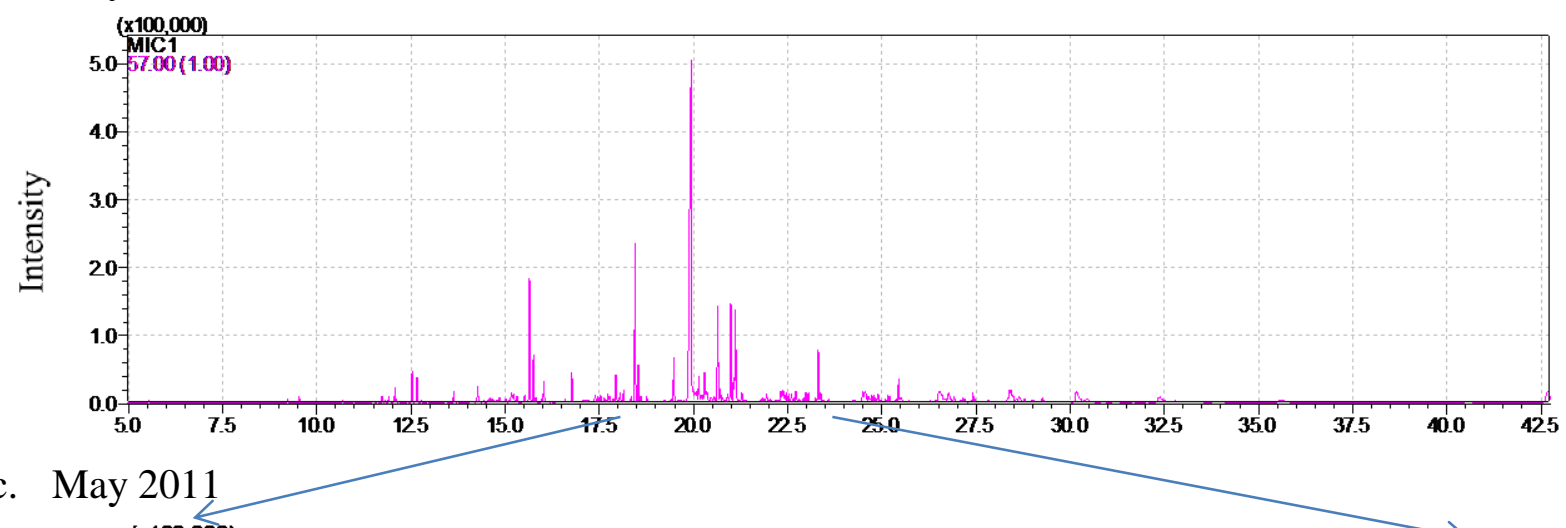

c. May 2011

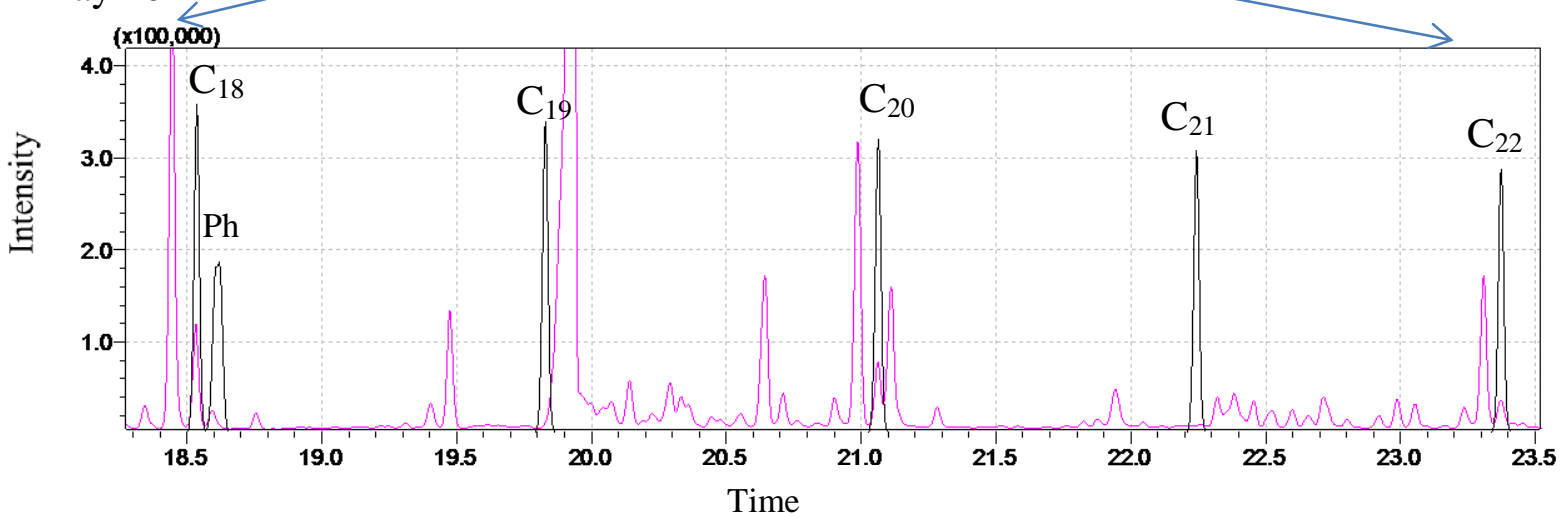

Figure S1. The GC/MS spectrum of hydrocarbons $(\mathrm{m} / \mathrm{z}=57)$ in dissolved waters collected at Sta. OSS in (a) May 2010 and (b) May 2011. A UCM was observed in the May 2010 water, but not the May 2011 water, indicating the oil contamination to the Sta. OSS water in May 2010 during the Deepwater Horizon oil spill. The total ion chromatograms (50-500 a.m.u.) basically showed similar patterns with ones at $\mathrm{m} / \mathrm{z}=57$ for the 2010 samples. (c) An expanded chromatogram in the retention time range of 18-23.5 min to show the dominance of even-carbon numbered $n$ alkanes $\left(\mathrm{C}_{18}, \mathrm{C}_{20}\right.$ and $\left.\mathrm{C}_{22}\right)$ in the OSS sample. The pink curve is the sample, and the black one refers to the $n$-alkane standards. 


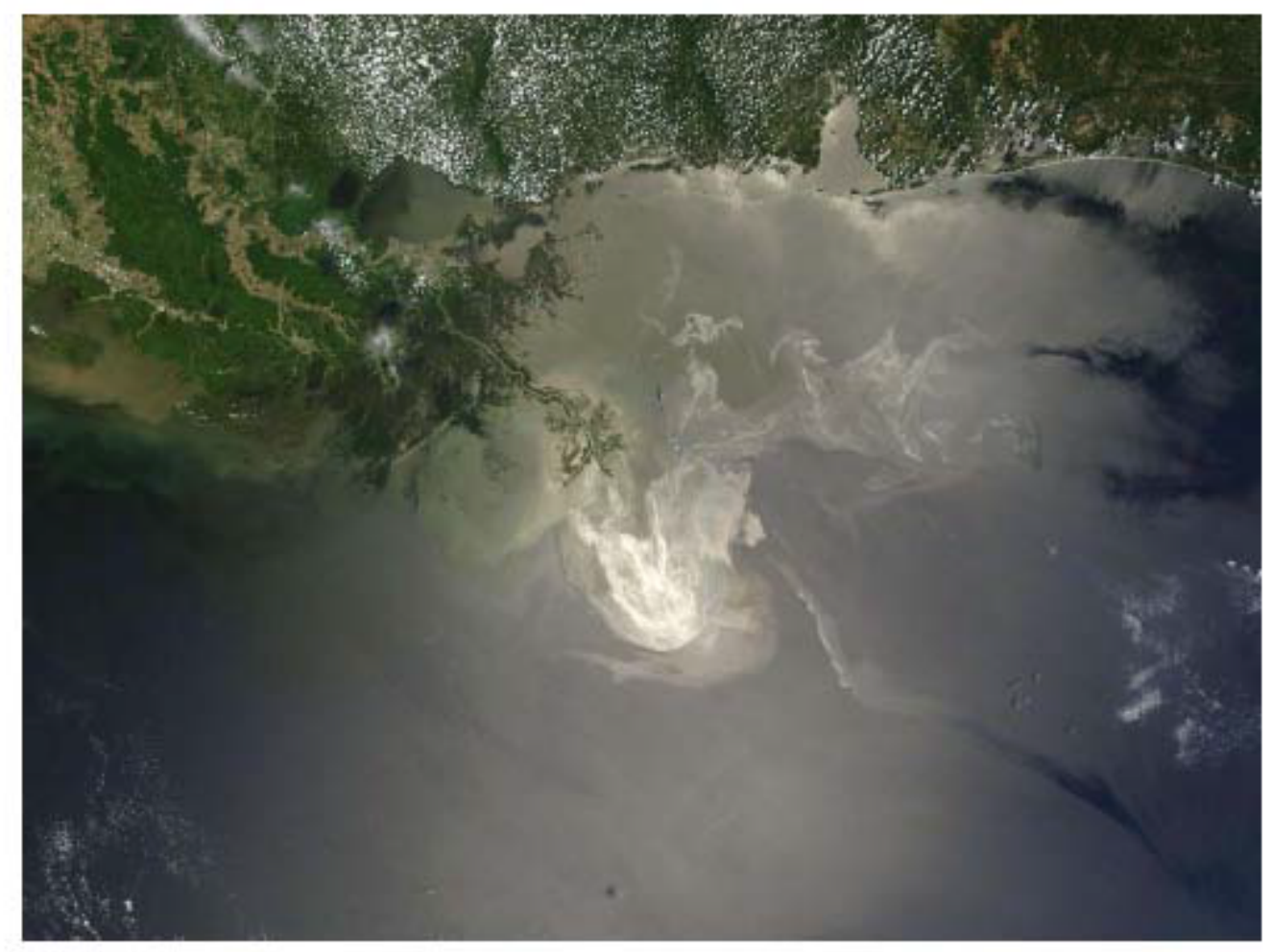

Figure S2. The image of the Mississippi Delta on May 24, 2011 by Terra Satellites

(http://www.nasa.gov/topics/earth/features/oilspill/oil_spill_gallery.html). This image clearly shows that the oil slicks from the BPDH oil spill on the sea surface of the Mississippi Delta area, impacting our sampling stations during the May cruise (May 20-27, 2010). On May 24, we were at station MRM sampling (Figure 1). 


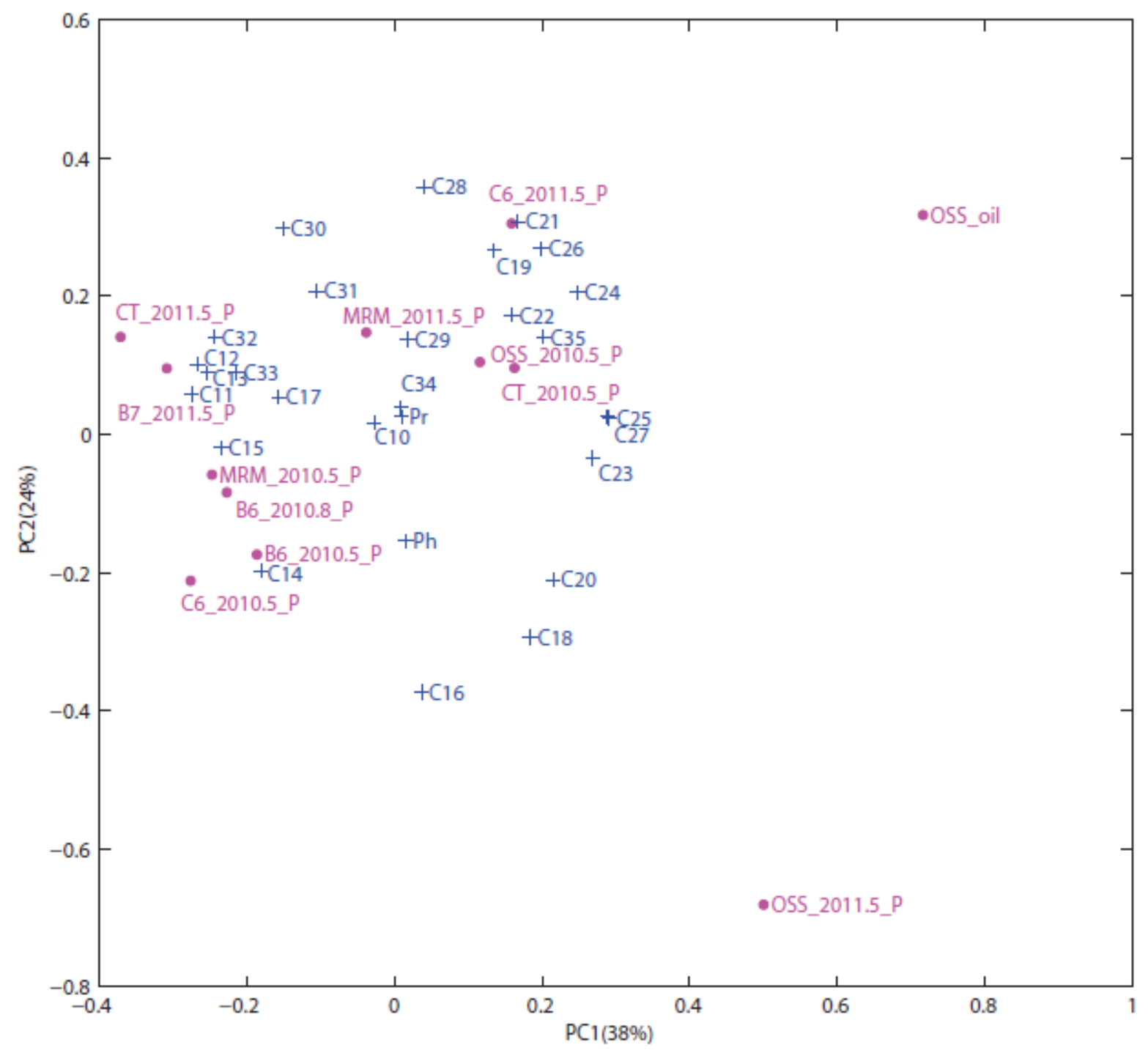

Figure S3. Principal component analysis on alkane compositions of particulate samples collected in May 2010, August 2010, and May 2011. An oil mousse sample collected in May 2010 was included (OSS_oil). There is no clear compositional patterns for the particulate samples, expect that the OSS particulate sample (OSS_2011.5_P) was dominated by even carbon-numbered nalkanes $\mathrm{C}_{16}-\mathrm{C}_{20}$. 